\title{
Improving long-term health outcomes of preterm infants: how to implement the findings of nutritional intervention studies into daily clinical practice
}

\author{
Charlotte A. Ruys ${ }^{1} \cdot$ Monique van de Lagemaat $^{1}$ (D) - Joost Rotteveel ${ }^{2} \cdot$ Martijn J. J. Finken $^{2} \cdot$ Harrie N. Lafeber $^{1}$
}

Received: 24 November 2020 / Revised: 11 January 2021 / Accepted: 14 January 2021 / Published online: 30 January 2021

(C) The Author(s) 2021

\begin{abstract}
Preterm-born children are at risk for later neurodevelopmental problems and cardiometabolic diseases; early-life growth restriction and suboptimal neonatal nutrition have been recognized as risk factors. Prevention of these long-term sequelae has been the focus of intervention studies. High supplies of protein and energy during the first weeks of life (i.e., energy $>100 \mathrm{kcal} \mathrm{kg}^{-1} \mathrm{day}^{-1}$ and a protein-to-energy ratio $>3 \mathrm{~g} / 100 \mathrm{kcal}$ ) were found to improve both early growth and later neurodevelopmental outcome. Discontinuation of this high-energy diet is advised beyond 32-34 weeks postconceptional age to prevent excess fat mass and possible later cardiometabolic diseases. After discharge, nutrition with a higher protein-to-energy ratio (i.e., $>2.5-3.0 \mathrm{~g} / 100 \mathrm{kcal}$ ) may improve growth and body composition in the short term.

Conclusion: Preterm infants in their first weeks of life require a high-protein high-energy diet, starting shortly after birth. Subsequent adjustments in nutritional composition, aimed at achieving optimal body composition and minimizing the long-term cardiometabolic risks without jeopardizing the developing brain, should be guided by the growth pattern. The long-term impact of this strategy needs to be studied.
\end{abstract}

\section{What is Known:}

- Preterm infants are at risk for nutritional deficiencies and extrauterine growth restriction.

- Extrauterine growth restriction and suboptimal nutrition are risk factors for neurodevelopmental problems and cardiometabolic disease in later life.

What is New:

- Postnatally, a shorter duration of high-energy nutrition may prevent excess fat mass accretion and its associated cardiometabolic risks and an early switch to a protein-enriched diet should be considered from 32-34 weeks postconceptional age.

- In case of formula feeding, re-evaluate the need for the continuation of a protein-enriched diet, based on the infant's growth pattern.

Keywords Preterm birth $\cdot$ Early nutrition $\cdot$ Postnatal growth restriction $\cdot$ Protein-to-energy ratio

Charlotte A. Ruys and Monique van de Lagemaat contributed equally to this review.

Communicated by Peter de Winter

Monique van de Lagemaat

m.vandelagemaat@amsterdamumc.nl

Charlotte A. Ruys

c.ruys@amsterdamumc.nl

Joost Rotteveel

j.rotteveel@amsterdamumc.nl

Martijn J. J. Finken

m.finken@amsterdamumc.nl
Harrie N. Lafeber

hn.lafeber@amsterdamumc.nl

1 Department of Pediatrics/Neonatology, Emma Children's Hospital, Amsterdam UMC, VU University Amsterdam, PO Box 7057, 1007 MB Amsterdam, The Netherlands

2 Department of Pediatric Endocrinology, Emma Children's Hospital, Amsterdam UMC, VU University Amsterdam,

Amsterdam, The Netherlands 


$\begin{array}{ll}\text { Abbreviations } \\ \text { AGA } & \text { Appropriate-for-gestational-age } \\ \text { CA } & \text { Corrected age } \\ \text { ESPGHAN } & \begin{array}{l}\text { European Society for Paediatric } \\ \text { Gastroenterology, Hepatology, and Nutrition }\end{array} \\ \text { EUGR } & \text { Extrauterine growth restriction } \\ \text { HM } & \text { Human milk } \\ \text { P:E ratio } & \text { Protein-to-energy ratio } \\ \text { SGA } & \text { Small-for-gestational-age } \\ \text { VLBW } & \text { Very low birth weight }\end{array}$

\section{Introduction}

Over the past decades, the incidence of preterm birth (i.e., before 37-week gestation) has increased from $7.2 \%$ in 1990 to $8.6 \%$ in 2010 in developed countries, with a relatively stable proportion of $15 \%$ very preterm births (i.e., before $32-$ week gestation) [1-4]. Meanwhile, owing to improvements in perinatal care, neonatal mortality after very preterm birth has decreased [5]. Nonetheless, the numbers with neonatal morbidities have remained unchanged or have even increased over time $[5,6]$. Similar observations were made for longterm cognitive and motor impairments [7, 8]. Preterm birth has also been associated with later cardiometabolic risks [9], which emphasizes the importance of strategies that aim to improve short- and long-term outcomes after very preterm birth.

Early-life growth and nutrition may modulate these risks. This review provides a brief summary of findings from nutritional intervention studies in preterm infants and gives practical suggestions for their nutritional management from birth to 6 months corrected age (CA; i.e., after term age).

\section{Growth after preterm birth and its impact on neurodevelopment and cardiometabolic risks}

Very preterm infants (i.e., gestational age $<32$ weeks) or very low birth weight infants (VLBW; i.e., birth weight $<1500 \mathrm{~g}$ ) are at risk for suboptimal postnatal growth during their extrauterine "third trimester" due to a combination of feeding problems, gut immaturity, and high nutritional demands (i.e., due to acute illnesses and rapid brain growth) [10]. Therefore, the first weeks after birth are characterized by a discrepancy between the nutritional demands and the nutritional supplies, which is particularly evident among ill preterm infants [11]. Accumulating deficits of energy and macronutrients result in extrauterine growth restriction (EUGR) in 33 to $90 \%$ of VLBW infants, depending on the definition [12-14]. There is controversy about the definition of EUGR, including cutoff level ( $<-2$ SDS vs $<10$ th percentile) and age of assessment (term age vs 36 weeks postconceptional age) [14-16]. In this review, all infants with weight below -2 SDS or below the 10 th percentile at term age or at 36 weeks CA were considered as having EUGR.

The third trimester of pregnancy is a period of rapid fetal brain growth and development in terms of cortical thickening, myelination, axonal development, vascularization, and cerebellar growth [17]. Preterm infants, specifically those who experienced EUGR, show delayed cortical maturation until term age [18] and impaired neurodevelopment in childhood [14-16] or at adolescence [19]. They are at increased risk for cognitive, behavioral, and motor problems [20, 21]. Onefourth of them has moderate to severe impairments [22]. The reduction in intelligence quotient score associated with prematurity has been estimated at $0.86 \mathrm{SD}$ [8]. Preterm infants experiencing a more rapid postnatal growth generally have a more favorable neurodevelopmental outcome [23, 24].

Furthermore, preterm birth has been associated with metabolic syndrome in later life [9, 25-34], which is a combination of increased fat mass, high blood pressure, dyslipidemia, and impaired glucose tolerance [35]. The link between prematurity and metabolic syndrome may be partly explained by catch-up growth after EUGR $[14,36]$. Although those born with extremely low birth weight (i.e., $<1000 \mathrm{~g}$ ) do experience accelerated postnatal growth, they still remain smaller and lighter throughout childhood than those term born with inconsistent findings with regard to body composition [37]. Nonetheless, catch-up growth accompanied by fat mass accretion exceeding linear growth predisposes to infant adiposity, and subsequent tracking of fat mass from infancy into childhood and adulthood predisposes to metabolic syndrome [38]. In line with these findings, more rapid weight-for-length increments during the first 3 months after preterm birth have been associated with metabolic syndrome components at age 18-24 years [39].

\section{Improvement of nutritional status and postnatal growth}

The high nutritional needs of preterm infants can only be met by a diet rich in carbohydrates, protein, and fat, starting shortly after birth. This window of opportunity has been the focus of multiple nutritional intervention studies [40, 41]. Most of these studies aim to achieve postnatal growth, fat mass excretion, and neurodevelopment similar to intrauterine norms. However, long-term follow-up of nutritional intervention studies is scarce [42]. Despite major improvements in the nutritional composition for preterm infants over the past decades $[43,44]$, cumulative nutritional deficits and EUGR are still common at the time of hospital discharge [45]. Therefore, nutritional interventions after discharge may also contribute to improving long-term outcomes [40, 41]. 


\section{Translating nutritional research into daily practice}

Based on the available evidence [46-49], we propose practical suggestions for the nutritional management of very preterm infants from (very) preterm birth until 32-34 weeks postconceptional age (part A), from 32 to 34 weeks postconceptional age until term age (part B), and from term age until 6 months CA (part C). Figures 1 and 2 provide a graphical representation of these practical suggestions and are based on the total protein and energy intakes that may theoretically be needed by these (very) preterm infants.

\section{Part A: Practical nutritional suggestions for (very) preterm infants from very preterm birth (i.e., gesta- tional age $<32$ weeks) until 32-34 weeks postconceptional age}

There is sufficient evidence to recommend an early initiation and a rapid advancement of protein and energy intakes in very preterm infants [43, 46, 50, 51]. From 24 weeks until 28-30 weeks postconceptional age, infants are admitted to a neonatal intensive care unit and require parenteral nutrition for the first 2 to 3 weeks of life to fulfill their nutritional demands. Meanwhile, enteral nutrition should be gradually increased. Studies conducted thus far show that providing preterm infants with $1.5 \mathrm{~g}$ of parenteral amino acids per kilogram per day within the first $24 \mathrm{~h}$ after birth and increasing its stepwise to $3.5-4.0 \mathrm{~g} \mathrm{~kg}^{-1}$ day $^{-1}$ is safe, and these intakes have been adhered to by current global guidelines on parenteral nutrition in VLBW infants [50, 54]. Furthermore, increased supplies of protein and energy during the first weeks of life improve neurodevelopmental outcome at 18 months of age $[52,53]$. After the advancement of enteral supplies, the enteral protein intake should add up to $3.5-4.5 \mathrm{~g} \mathrm{~kg}^{-1}$ day $^{-1}$ (for birth weight below $1000 \mathrm{~g}$ : 4.0-4.5 $\mathrm{g} \mathrm{kg}^{-1} \mathrm{day}^{-1}$; for birth weight 1000 $1800 \mathrm{~g}: 3.5-4.0 \mathrm{~g} \mathrm{~kg}^{-1} \mathrm{day}^{-1}$ ) and the energy intake to 110 $135 \mathrm{kcal} \mathrm{kg}^{-1}$ day $^{-1}$, in line with ESPGHAN recommendations (Fig. 1) [45, 47, 55]. In practice, these protein and energy intakes can be achieved with human milk (HM), either mother's own milk or donor milk, with the addition of a breast milk fortifier and, if necessary, protein enrichment. When formula fed, these intakes can be achieved with a preterm formula with sufficiently high-protein content. A Cochrane review demonstrates that a formula with a protein content of $1.7 \mathrm{~g} /$ $100 \mathrm{ml}$ already results in a modest effect on growth rates during hospital admission in preterm infants with a birth weight $\leq 1850 \mathrm{~g}$ [48]. Moreover, another Cochrane review states low-certainty evidence of improved weight gain during hospital admission with high $\left(>3 \mathrm{~g} \mathrm{~kg}^{-1}\right.$ day $\left.^{-1}\right)$ compared to low $\left(<3 \mathrm{~g} \mathrm{~kg}^{-1} \mathrm{day}^{-1}\right)$ protein intake from formula [56].

However, controversy exists on the further benefit on weight gain before discharge with a very high enteral protein intake $\left(>4 \mathrm{~g} \mathrm{~kg}^{-1}\right.$ day $\left.^{-1}\right)$ as one study describes the increase in
Fig. 1 Recommendations for protein intake (a) and energy intake (b) from birth until 6 months corrected age represented as means with ranges (colored dotted lines) from parenteral (blue) and enteral (red) nutrition. Vertical dotted lines represent the "transition period" from 32 to 34 weeks postconceptional age to term age when energy intake may be (gradually) lowered to $115 \mathrm{kcal}$ $\mathrm{kg}^{-1} \mathrm{day}^{-1}$ with a protein intake of $\geq 3 \mathrm{~g} \mathrm{~kg}^{-1}$ day $^{-1}$, provided that growth is age appropriate (i.e., $10-15 \mathrm{~g} \mathrm{~kg}^{-1} \mathrm{~s}^{1 a y}{ }^{-1}$ for at least 1 week) $[45,47]$. Total protein intake from combined parenteral and enteral nutrition should not exceed $4.5 \mathrm{~g} \mathrm{~kg}^{-1}$ day $^{-1}$; total energy intake from combined parenteral and enteral nutrition should not exceed $135 \mathrm{kcal} \mathrm{kg}^{-1}$ day $^{-1}$

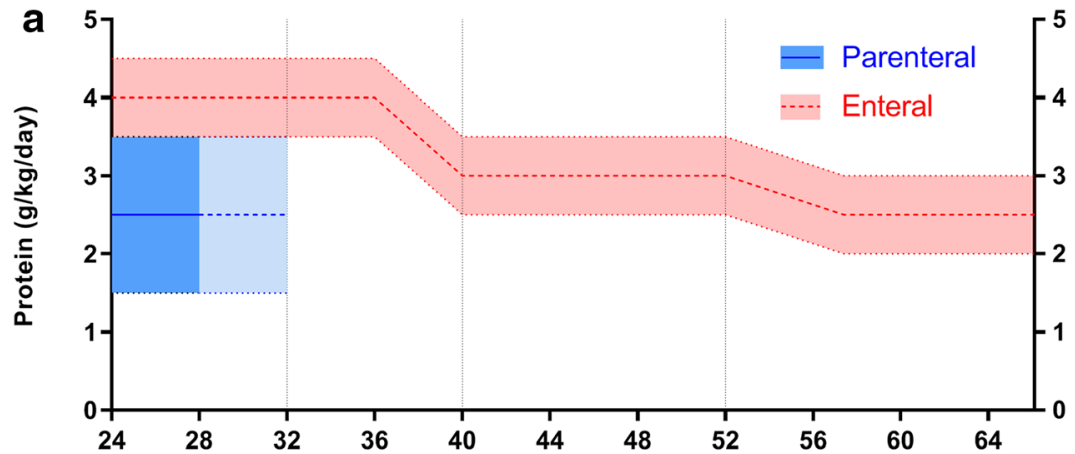

(Gestational) age in weeks

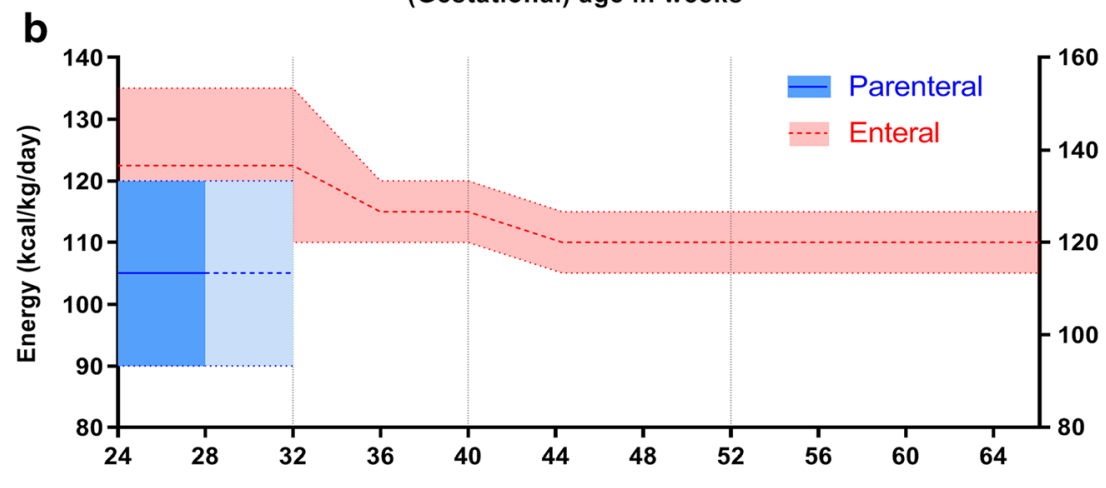

(Gestational) age in weeks 


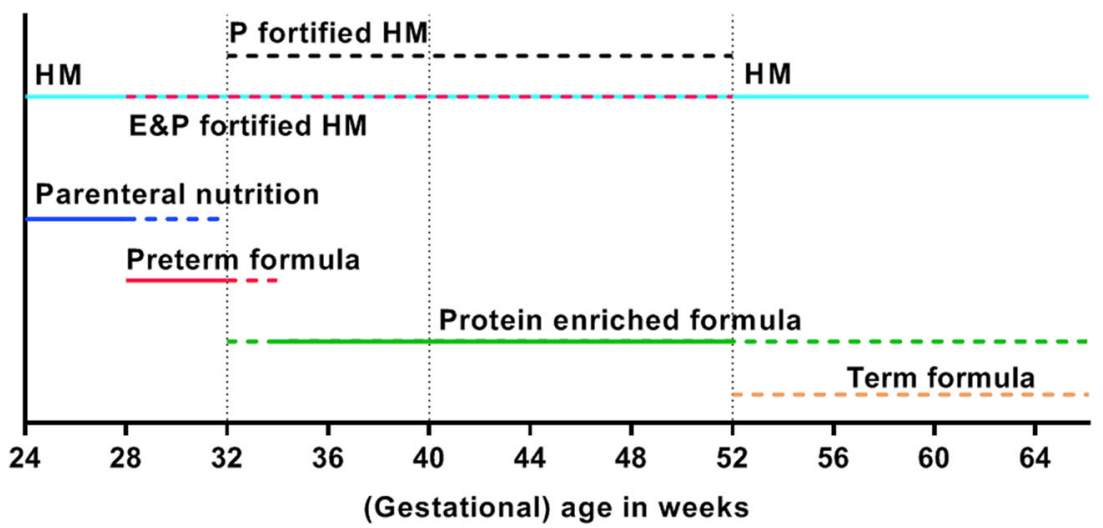

Fig. 2 Recommendations for the type of nutrition (colored horizontal lines) from birth until 6 months corrected age. Vertical dotted lines represent "transition periods" from 32 to 34 weeks postconceptional age to term age when energy intake may be (gradually) lowered to $115 \mathrm{kcal}$ $\mathrm{kg}^{-1}$ day ${ }^{-1}$ with a protein intake of $\geq 3 \mathrm{~g} \mathrm{~kg}^{-1} \mathrm{day}^{-1}$, provided that growth is age appropriate (i.e., $10-15 \mathrm{~g} \mathrm{~kg}^{-1} \mathrm{day}^{-1}$ for at least 1 week) [45, 47] weight gain [57], whereas others, including a recent Cochrane review, do not find any benefits $[56,58,59]$. Not only quantitative weight gain but also lean mass may be influenced by higher protein intake during the hospital stay with a higher increase in lean mass with protein intake up to $4 \mathrm{~g} \mathrm{~kg}^{-1}$ day $^{-1}$ [57]. In addition, among very preterm and VLBW infants, an insufficient protein intake during the first weeks of life is associated with decreases in lean mass and resting energy expenditure in adulthood [60], while excess energy intake (i.e., an intake exceeding the amount needed for appropriate growth) has been associated with gains in fat mass [61, $62]$.

There is a prominent role for the use of fortified human milk (HM), either own mother's milk or donor HM [47, 63, 64], but randomized trials comparing growth in very preterm infants fed preterm formula or HM during a hospital stay are not available [48]. Observational studies inconsistently show improved growth up to 12 months CA with preterm formula in one study [65] and no difference in growth between preterm formula or HM in another [66]. A meta-analysis of six trials shows higher (absolute and relative) fat mass at term age in very preterm infants fed formula compared to HM [67]. When comparing preterm formula to donor HM, a systematic review shows that very preterm infants fed preterm formula demonstrate faster growth before hospital discharge [49].

As shown by Cochrane reviews and several studies, multinutrient fortification of HM results in improved growth in the short term [64, 68-70], which does not sustain during the first year of life. In particular, protein supplementation to HM increases short-term rates of weight, length, and head circumference gain in preterm infants during hospital admission $[68,71,72]$ without a clear evidence of a higher risk of necrotizing enterocolitis or feeding intolerance [68]. There is insufficient evidence for the effect of fat or carbohydrate supplementation to HM on growth rate [73, 74]. In addition, there is some evidence suggesting that HM might protect against metabolic syndrome [75]. This protective effect of HM might be explained by a favorable early growth pattern as compared with formula feeding [75]. Ideally, HM fortification should be individualized since it has been demonstrated that substantial inter-individual variation in macronutrient contents of (preterm) HM could explain differences in growth velocity [76]. A preterm formula can serve as an (second best) alternative if donor HM is not available or refused by parents (Table 1), in spite of a higher risk of feeding intolerance and necrotizing enterocolitis compared to donor HM [48, 49, 77, 78].

In summary, in clinical practice, initial parenteral nutrition may be rapidly increased with regard to protein intake from $1.5 \mathrm{~g} \mathrm{~kg}^{-1}$ day $^{-1}$ during the first $24 \mathrm{~h}$ to $3.5-4.0 \mathrm{~g} \mathrm{~kg}^{-1}$ day $^{-1}$ thereafter. With the advancement of enteral nutrition, it is advised to use (donor) HM with multinutrient or protein fortification as the first choice of enteral feeding and preterm formula as a second-best alternative. Total enteral and parenteral intake should aim at an energy intake of 110-135 kcal $\mathrm{kg}^{-1} \mathrm{day}^{-1}$ and a protein intake of 4.0-4.5 $\mathrm{g} \mathrm{kg}^{-1}$ day $^{-1}$ for preterm infants with a birth weight below $1000 \mathrm{~g}$ and a protein intake of 3.5-4.0 $\mathrm{g} \mathrm{kg}^{-1}$ day $^{-1}$ for preterm infants with a birth weight of 1000-1800 g.

\section{Part B: Practical nutritional suggestions from 32-34 weeks postconceptional age to term age}

In addition to the ESPGHAN recommendations, we suggest that nutritional decision-making from 32-34 weeks postconceptional age is guided by the infant's growth pattern. From that age onwards, the energy intake may be lowered from 135 to around $115 \mathrm{kcal} \mathrm{kg}^{-1}$ day $^{-1}$ (Fig. 1), provided that growth is $10-15 \mathrm{~g} \mathrm{~kg}^{-1}$ day $^{-1}$ for at least 1 week, similar to fetal growth [45, 47]. Beyond 32-34 weeks postconceptional age, a high-caloric diet may lead to excessive fat mass gain [79] and a switch to a mainly proteinenriched diet might be necessary to ensure optimal lean mass relative to fat mass accretion. While gradually tapering the 
Table 1 Composition of different types of (preterm) infant nutrition per $100 \mathrm{ml}$

\begin{tabular}{|c|c|c|c|c|c|c|c|c|}
\hline & $\mathrm{HM}$ term $^{\mathrm{a}}$ & $\begin{array}{l}\mathrm{HM} \\
\text { preterm }^{\mathrm{a}}\end{array}$ & $\begin{array}{l}\mathrm{HM} \\
\text { fortifier }\end{array}$ & $\begin{array}{l}\text { HM protein } \\
\text { fortifier }^{b}\end{array}$ & $\begin{array}{l}\text { Preterm } \\
\text { formula }\end{array}$ & $\begin{array}{l}\text { Energy \& protein-enriched } \\
\text { formula }\end{array}$ & $\begin{array}{l}\text { Protein- } \\
\text { enriched } \\
\text { formula }\end{array}$ & $\begin{array}{l}\text { Standard term } \\
\text { formula }\end{array}$ \\
\hline Energy (kcal) & 68 & 65 & $14-16$ & 3.4 & $79-100$ & $74-77$ & $66-68$ & $64-68$ \\
\hline Protein (g) & 1.0 & 1.5 & $1.0-1.2$ & 0.8 & $2.6-3.0$ & $2.0-2.1$ & $2.0-2.2$ & $1.3-1.4$ \\
\hline $\mathrm{P}:$ E ratio & 1.5 & 2.3 & - & - & $3.0-3.6$ & $2.7-2.8$ & $3.0-3.3$ & $2.0-2.1$ \\
\hline Carbohydrates (g) & 7.0 & 7.2 & $1.8-2.8$ & 0.02 & $7.8-9.6$ & $7.5-7.8$ & $6.6-7.3$ & $6.9-7.6$ \\
\hline Lipids (g) & 4.0 & 3.5 & - & 0.001 & $3.9-6.7$ & $4.0-4.1$ & $3.4-3.7$ & $3.4-3.6$ \\
\hline Calcium (mg) & 30 & 25 & $66-116$ & 5.2 & $96-183$ & $53-120$ & $66-165$ & $44-57$ \\
\hline Phosphate (mg) & 15 & 14 & $38-64$ & 5.2 & $54-101$ & $46-66$ & 39-90 & $26-43$ \\
\hline Iron (mg) & 0.1 & 0 & $0-0.32$ & - & $1.5-1.8$ & $1.2-1.8$ & $0.9-1.8$ & $0.4-1.8$ \\
\hline Vitamin D ( $\mu \mathrm{g})$ & 0 & 0 & $3.0-5.0$ & - & $1.9-7.5$ & $1.3-3.1$ & $1.3-7.5$ & $1.2-1.5$ \\
\hline
\end{tabular}

Based on available products in Europe (Nenatal/Nutrilon Nutricia, HeroBaby, Humana, Nutriprem Cow\&Gate, Enfamil Mead Johnson, Similac Abbott) ${ }^{a}$ Based on Gidrewicz et al. [98] and Boyce et al. [99]

${ }^{\mathrm{b}}$ Per sachet of $1 \mathrm{~g}$. (E\&)P-enriched formula, (energy\&) protein-enriched formula; $H M$, human milk; $H M F$, human milk fortifier; $H M P F$, human milk protein fortifier; $P: E$ ratio, protein-to-energy ratio; STF, standard term formula

amount of energy from 32-34 weeks postconceptional age onward, high-protein supplies $\left(\geq 3 \mathrm{~g} \mathrm{~kg}^{-1} \mathrm{day}^{-1}\right.$ ) resulting in a higher protein-to-energy (P:E) ratio must be maintained to meet the requirements for linear growth and brain development $[47,68]$. Prolongation of human milk fortification with protein until term age or use of a protein- but not energyfortified formula may be considered during this period. To date, there are no meta-analyses or systematic reviews available to support this suggestion.

\section{Part C: Practical nutritional suggestions from term age until 6 months CA}

From term age onwards, we recommend maintaining the intake of energy and protein at $\sim 110 \mathrm{kcal} \mathrm{kg}^{-1} \mathrm{day}^{-1}$ and $\sim 3 \mathrm{~g}$ $\mathrm{kg}^{-1} \mathrm{day}^{-1}$, respectively (Fig. 1) [47]. Preterm infants who are completely HM fed will most likely drink directly from the breast by this time, making fortification impractical. The protein and energy contents of HM are lower than recommended. Therefore, we suggest close monitoring of the infant's growth pattern. Protein fortification of HM beyond term age should only be considered if steady growth has not yet been established.

In preterm infants who are formula fed, the recommended protein and energy intakes are covered by (energyand-)protein-enriched (so-called postdischarge) formulas (Table 1 and Fig. 1). The ESPGHAN advises to use such formulas up until 40 to 52 weeks postconceptional age (i.e., until term age to 3 months $\mathrm{CA}$ ) and, thereafter, to switch to standard term formula [47]. To date, there is no compelling evidence for an effect of nutrient-enriched formulas on growth or neurodevelopment $[46,80]$. Nevertheless, a higher P:E ratio tends to be associated with improved growth and body composition during the first 6 months [46, 81-86], albeit not unequivocally [87-90]. Long-term follow-up data among infants born very preterm and/or with VLBW show that the short-term benefits on body composition of a proteinenriched formula (with a P:E ratio of $2.52 \mathrm{~g}$ per $100 \mathrm{kcal}$ ) after discharge were no longer present at age 8 years [91]. In addition, their neurodevelopmental outcomes at 18 and 24 months $\mathrm{CA}$ and at age 8 years were no different from those fed a standard formula after discharge [80, 89, 92, 93]. However, post hoc analyses show that preterm infants with limited postnatal weight gain during the first 6 months after term age receiving protein-enriched formula were taller and had more lean mass at age 8 years [91]. Because of the large proportion of preterm infants that are growth-restricted at term age [12, 13], we suggest a continuation of an (energy-and-)proteinenriched formula until at least 3 months CA in formula-fed preterm infants. However, this nutritional suggestion should be balanced against observations in term-born children, which suggest that excess protein intake during the first 2 years of life may predispose to later obesity [94]. Therefore, caution is warranted with the use of (energy-and-)protein-enriched formulas beyond 3 months $\mathrm{CA}$. Evaluation of the growth pattern should guide the decision whether or not to continue proteinenriched formulas beyond 3 months $\mathrm{CA}$ up to a maximum of 6 months CA. This is only possible by using an individual approach with frequent follow-up of weight, length, head circumference, and, preferably, an estimate of body composition. Growth is preferably evaluated with postnatal growth curves for preterm infants $[95,96]$. Factors such as the degree of IUGR at preterm birth and early postnatal growth (deviation from the norm) will guide the decision to fortify nutrition with 
extra energy and/or protein or to change to standard term formula or human milk without fortification sooner.

\section{Conclusions}

Adequate supplies of nutrients shortly after preterm birth reduce the risk of suboptimal postnatal growth and, consequently, the risk of adverse neurodevelopmental outcome. A nutritional switch from a high-energy and high-protein diet to a high-protein-only diet should be considered during hospital admission from a postconceptional age of 32-34 weeks onwards. Human milk is the feeding of choice for preterm infants. In case of formula feeding, the continuation of proteinenriched formula should be reconsidered at 3 months CA based on the infant's growth pattern [97]. More individualized nutritional care seems warranted. These nutritional suggestions may contribute to acknowledging the in-hospital and postdischarge periods as a continuum instead of separate entities, resulting in healthier early growth and a reduction of the associated risks of neurodevelopmental problems and cardiometabolic diseases.

Authors' contributions C.A. Ruys, M. van de Lagemaat, and H.N. Lafeber had the idea for the article. C.A. Ruys and M. van de Lagemaat performed the literature search and drafted the manuscript. All authors critically revised the previous versions of the manuscript and approved the final version.

Data availability Not applicable.

\section{Compliance with ethical standards}

Conflict of interest The authors declare no conflict of interest.

Ethics approval and consent to participate Not applicable.

Consent for publication Not applicable.

Material availability Not applicable.

Code availability Not applicable.

Open Access This article is licensed under a Creative Commons Attribution 4.0 International License, which permits use, sharing, adaptation, distribution and reproduction in any medium or format, as long as you give appropriate credit to the original author(s) and the source, provide a link to the Creative Commons licence, and indicate if changes were made. The images or other third party material in this article are included in the article's Creative Commons licence, unless indicated otherwise in a credit line to the material. If material is not included in the article's Creative Commons licence and your intended use is not permitted by statutory regulation or exceeds the permitted use, you will need to obtain permission directly from the copyright holder. To view a copy of this licence, visit http://creativecommons.org/licenses/by/4.0/.

\section{References}

1. Blencowe H, Cousens S, Oestergaard MZ, Chou D, Moller AB, Narwal R, Adler A, Vera Garcia C, Rohde S, Say L, Lawn JE (2012) National, regional, and worldwide estimates of preterm birth rates in the year 2010 with time trends since 1990 for selected countries: a systematic analysis and implications. Lancet 379: 2162-2172

2. Shah PS, Lui K, Sjors G, Mirea L, Reichman B, Adams M, Modi N, Darlow BA, Kusuda S, San Feliciano L, Yang J, Hakansson S, Mori R, Bassler D, Figueras-Aloy J, Lee SK (2016) Neonatal outcomes of very low birth weight and very preterm neonates: an international comparison. J Pediatr 177:144-152 e146

3. Zeitlin J, Szamotulska K, Drewniak N, Mohangoo AD, Chalmers J, Sakkeus L, Irgens L, Gatt M, Gissler M, Blondel B (2013) Preterm birth time trends in Europe: a study of 19 countries. BJOG : an international journal of obstetrics and gynaecology 120:1356-1365

4. Beck S, Wojdyla D, Say L, Betran AP, Merialdi M, Requejo JH, Rubens C, Menon R, Van Look PF (2010) The worldwide incidence of preterm birth: a systematic review of maternal mortality and morbidity. Bull World Health Organ 88:31-38

5. Stoll BJ, Hansen NI, Bell EF, Walsh MC, Carlo WA, Shankaran S, Laptook AR, Sanchez PJ, Van Meurs KP, Wyckoff M, Das A, Hale EC, Ball MB, Newman NS, Schibler K, Poindexter BB, Kennedy KA, Cotten CM, Watterberg KL, D'Angio CT, DeMauro SB, Truog WE, Devaskar U, Higgins RD (2015) Trends in care practices, morbidity, and mortality of extremely preterm neonates, 1993-2012. Jama 314:1039-1051

6. Costeloe KL, Hennessy EM, Haider S, Stacey F, Marlow N, Draper ES (2012) Short term outcomes after extreme preterm birth in England: comparison of two birth cohorts in 1995 and 2006 (the EPICure studies). BMJ 345:e7976

7. Spittle AJ, Cameron K, Doyle LW, Cheong JL (2018) Motor impairment trends in extremely preterm children: 1991-2005. Pediatrics 141:e20173410

8. Twilhaar ES, Wade RM, de Kieviet JF, van Goudoever JB, van Elburg RM, Oosterlaan J (2018) Cognitive outcomes of children born extremely or very preterm since the 1990 s and associated risk factors: a meta-analysis and meta-regression. JAMA Pediatr 172: 361-367

9. Sipola-Leppanen M, Kajantie E (2015) Should we assess cardiovascular risk in young adults born preterm? Curr Opin Lipidol 26: 282-287

10. Leaf A (2013) Introducing enteral feeds in the high-risk preterm infant. Semin Fetal Neonatal Med 18:150-154

11. Ehrenkranz RA, Das A, Wrage LA, Poindexter BB, Higgins RD, Stoll BJ, Oh W (2011) Early nutrition mediates the influence of severity of illness on extremely LBW infants. Pediatr Res 69: $522-529$

12. Stevens TP, Shields E, Campbell D, Combs A, Horgan M, La Gamma EF, Xiong K, Kacica M (2018) Statewide initiative to reduce postnatal growth restriction among infants $<31$ weeks of gestation. J Pediatr 197:82-89 e82

13. Hiltunen H, Loyttyniemi E, Isolauri E, Rautava S (2018) Early nutrition and growth until the corrected age of 2 years in extremely preterm infants. Neonatology 113:100-107

14. Martinez-Jimenez MD, Gomez-Garcia FJ, Gil-Campos M, PerezNavero JL (2020) Comorbidities in childhood associated with extrauterine growth restriction in preterm infants: a scoping review. Eur J Pediatr 179:1255-1265

15. Guellec I, Lapillonne A, Marret S, Picaud JC, Mitanchez D, Charkaluk ML, Fresson J, Arnaud C, Flamand C, Cambonie G, Kaminski M, Roze JC, Ancel PY (2016) Effect of intra- and extrauterine growth on long-term neurologic outcomes of very preterm infants. J Pediatr 175:93-99.e91 
16. Fenton TR, Cormack B, Goldberg D, Nasser R, Alshaikh B, Eliasziw M, Hay WW, Hoyos A, Anderson D, Bloomfield F, Griffin I, Embleton N, Rochow N, Taylor S, Senterre T, Schanler RJ, Elmrayed S, Groh-Wargo S, Adamkin D, Shah PS (2020) "Extrauterine growth restriction" and "postnatal growth failure" are misnomers for preterm infants. J Perinatol 40:704-714

17. Volpe JJ (2009) Brain injury in premature infants: a complex amalgam of destructive and developmental disturbances. Lancet Neurol 8:110-124

18. Vinall J, Grunau RE, Brant R, Chau V, Poskitt KJ, Synnes AR, Miller SP (2013) Slower postnatal growth is associated with delayed cerebral cortical maturation in preterm newborns. Science translational medicine 5:168ra168

19. Sammallahti S, Pyhala R, Lahti M, Lahti J, Pesonen AK, Heinonen K, Hovi P, Eriksson JG, Strang-Karlsson S, Andersson S, Jarvenpaa AL, Kajantie E, Raikkonen K (2014) Infant growth after preterm birth and neurocognitive abilities in young adulthood. $\mathrm{J}$ Pediatr 165:1109-1115.e1103

20. Bhutta AT, Cleves MA, Casey PH, Cradock MM, Anand KJ (2002) Cognitive and behavioral outcomes of school-aged children who were born preterm: a meta-analysis. Jama 288:728-737

21. de Kieviet JF, Piek JP, Aarnoudse-Moens CS, Oosterlaan J (2009) Motor development in very preterm and very low-birth-weight children from birth to adolescence: a meta-analysis. JAMA 302:22352242

22. Blencowe H, Lee AC, Cousens S, Bahalim A, Narwal R, Zhong N, Chou D, Say L, Modi N, Katz J, Vos T, Marlow N, Lawn JE (2013) Preterm birth-associated neurodevelopmental impairment estimates at regional and global levels for 2010. Pediatr Res 74(Suppl 1):1734

23. Belfort MB, Rifas-Shiman SL, Sullivan T, Collins CT, McPhee AJ, Ryan P, Kleinman KP, Gillman MW, Gibson RA, Makrides M (2011) Infant growth before and after term: effects on neurodevelopment in preterm infants. Pediatrics 128:e899-e906

24. Ruys CA, Hollanders JJ, Broring T, van Schie PEM, van der Pal SM, van de Lagemaat M, Lafeber HN, Rotteveel J, Finken MJJ (2018) Early-life growth of preterm infants and its impact on neurodevelopment. Pediatr Res

25. de Jong F, Monuteaux MC, van Elburg RM, Gillman MW, Belfort MB (2012) Systematic review and meta-analysis of preterm birth and later systolic blood pressure. Hypertension 59:226-234

26. Parkinson JR, Hyde MJ, Gale C, Santhakumaran S, Modi N (2013) Preterm birth and the metabolic syndrome in adult life: a systematic review and meta-analysis. Pediatrics 131:e1240-e1263

27. Hovi P, Andersson S, Eriksson JG, Jarvenpaa AL, Strang-Karlsson S, Makitie O, Kajantie E (2007) Glucose regulation in young adults with very low birth weight. N Engl J Med 356:2053-2063

28. Sipola-Leppanen M, Vaarasmaki M, Tikanmaki M, Matinolli HM, Miettola S, Hovi P, Wehkalampi K, Ruokonen A, Sundvall J, Pouta A, Eriksson JG, Jarvelin MR, Kajantie E (2015) Cardiometabolic risk factors in young adults who were born preterm. Am J Epidemiol 181:861-873

29. Breukhoven PE, Kerkhof GF, Willemsen RH, Hokken-Koelega AC (2012) Fat mass and lipid profile in young adults born preterm. J Clin Endocrinol Metab 97:1294-1302

30. Lawlor DA, Davey Smith G, Clark H, Leon DA (2006) The associations of birthweight, gestational age and childhood BMI with type 2 diabetes: findings from the Aberdeen Children of the 1950s cohort. Diabetologia 49:2614-2617

31. Pilgaard K, Faerch K, Carstensen B, Poulsen P, Pisinger C, Pedersen O, Witte DR, Hansen T, Jorgensen T, Vaag A (2010) Low birthweight and premature birth are both associated with type 2 diabetes in a random sample of middle-aged Danes. Diabetologia 53:2526-2530
32. Hofman PL, Regan F, Jackson WE, Jefferies C, Knight DB, Robinson EM, Cutfield WS (2004) Premature birth and later insulin resistance. N Engl J Med 351:2179-2186

33. Mathai S, Derraik JG, Cutfield WS, Dalziel SR, Harding JE, Biggs J, Jefferies C, Hofman PL (2013) Increased adiposity in adults born preterm and their children. PLoS One 8:e81840

34. Ueda P, Cnattingius S, Stephansson O, Ingelsson E, Ludvigsson JF, Bonamy AK (2014) Cerebrovascular and ischemic heart disease in young adults born preterm: a population-based Swedish cohort study. Eur J Epidemiol 29:253-260

35. Alberti KG, Eckel RH, Grundy SM, Zimmet PZ, Cleeman JI, Donato KA, Fruchart JC, James WP, Loria CM, Smith SC Jr (2009) Harmonizing the metabolic syndrome: a joint interim statement of the International Diabetes Federation Task Force on Epidemiology and Prevention; National Heart, Lung, and Blood Institute; American Heart Association; World Heart Federation; International Atherosclerosis Society; and International Association for the Study of Obesity. Circulation 120:1640-1645

36. Euser AM, de Wit CC, Finken MJ, Rijken M, Wit JM (2008) Growth of preterm born children. Horm Res 70:319-328

37. Van de Pol C, Allegaert K (2020) Growth patterns and body composition in former extremely low birth weight (ELBW) neonates until adulthood: a systematic review. Eur J Pediatr 179:757-771

38. Singh AS, Mulder C, Twisk JW, van Mechelen W, Chinapaw MJ (2008) Tracking of childhood overweight into adulthood: a systematic review of the literature. Obes Rev 9:474-488

39. Kerkhof GF, Willemsen RH, Leunissen RW, Breukhoven PE, Hokken-Koelega AC (2012) Health profile of young adults born preterm: negative effects of rapid weight gain in early life. J Clin Endocrinol Metab 97:4498-4506

40. Schneider N, Garcia-Rodenas CL (2017) Early nutritional interventions for brain and cognitive development in preterm infants: a review of the literature. Nutrients 9

41. Hay WW Jr (2008) Strategies for feeding the preterm infant. Neonatology 94:245-254

42. Fewtrell MS, Domellof M, Hojsak I, Hulst JM, Kennedy K, Koletzko B, Mihatsh W, Stijnen T (2016) Attrition in long-term nutrition research studies: a commentary by the European Society for Pediatric Gastroenterology, Hepatology, and Nutrition Early Nutrition Research Working Group. J Pediatr Gastroenterol Nutr 62:180-182

43. Senterre T, Rigo J (2012) Reduction in postnatal cumulative nutritional deficit and improvement of growth in extremely preterm infants. Acta Paediatr 101:e64-e70

44. Schneider J, Fischer Fumeaux CJ, Duerden EG, Guo T, Foong J, Graz MB, Hagmann P, Chakravarty MM, Huppi PS, Beauport L, Truttmann AC, Miller SP (2018) Nutrient intake in the first two weeks of life and brain growth in preterm neonates. Pediatrics 141:e20172169

45. Lapillonne A, O'Connor DL, Wang D, Rigo J (2013) Nutritional recommendations for the late-preterm infant and the preterm infant after hospital discharge. J Pediatr 162:S90-S100

46. Teller IC, Embleton ND, Griffin IJ, van Elburg RM (2016) Postdischarge formula feeding in preterm infants: a systematic review mapping evidence about the role of macronutrient enrichment. Clin Nutr 35:791-801

47. Agostoni C, Buonocore G, Carnielli VP, De Curtis M, Darmaun D, Decsi T, Domellof M et al (2010) Enteral nutrient supply for preterm infants: commentary from the European Society of Paediatric Gastroenterology, Hepatology and Nutrition Committee on Nutrition. J Pediatr Gastroenterol Nutr 50:85-91

48. Brown JVE, Walsh V, McGuire W (2019) Formula versus maternal breast milk for feeding preterm or low birth weight infants. Cochrane Database Syst Rev 8:CD002972 
49. Quigley M, Embleton ND, McGuire W (2019) Formula versus donor breast milk for feeding preterm or low birth weight infants. Cochrane Database Syst Rev 7:CD002971

50. Ehrenkranz RA (2007) Early, aggressive nutritional management for very low birth weight infants: what is the evidence? Semin Perinatol 31:48-55

51. Embleton ND, van den Akker CHP (2019) Protein intakes to optimize outcomes for preterm infants. Semin Perinatol 43:151154

52. Stephens BE, Walden RV, Gargus RA, Tucker R, McKinley L, Mance M, Nye J, Vohr BR (2009) First-week protein and energy intakes are associated with 18-month developmental outcomes in extremely low birth weight infants. Pediatrics 123:1337-1343

53. Lucas A, Morley R, Cole TJ, Gore SM, Lucas PJ, Crowle P, Pearse R, Boon AJ, Powell R (1990) Early diet in preterm babies and developmental status at 18 months. Lancet 335:1477-1481

54. van Goudoever JB, Carnielli V, Darmaun D, Sainz de Pipaon M (2018) ESPGHAN/ESPEN/ESPR guidelines on pediatric parenteral nutrition: amino acids. Clin Nutr

55. Senterre T, Rigo J (2011) Optimizing early nutritional support based on recent recommendations in VLBW infants and postnatal growth restriction. J Pediatr Gastroenterol Nutr 53:536-542

56. Fenton TR, Al-Wassia H, Premji SS, Sauve RS (2020) Higher versus lower protein intake in formula-fed low birth weight infants. Cochrane Database Syst Rev 6:CD003959

57. Costa-Orvay JA, Figueras-Aloy J, Romera G, Closa-Monasterolo R, Carbonell-Estrany X (2011) The effects of varying protein and energy intakes on the growth and body composition of very low birth weight infants. Nutr J 10:140

58. Olsen IE, Harris CL, Lawson ML, Berseth CL (2014) Higher protein intake improves length, not weight, $\mathrm{z}$ scores in preterm infants. J Pediatr Gastroenterol Nutr 58:409-416

59. Atchley CB, Cloud A, Thompson D, Blunt MH, Satnes KJ, Szyld E, Ernst KD (2019) Enhanced protein diet for preterm infants: a prospective, randomized, double-blind, controlled trial. J Pediatr Gastroenterol Nutr 69:218-223

60. Matinolli HM, Hovi P, Mannisto S, Sipola-Leppanen M, Eriksson JG, Makitie O, Jarvenpaa AL, Andersson S, Kajantie E (2015) Early protein intake is associated with body composition and resting energy expenditure in young adults born with very low birth weight. J Nutr 145:2084-2091

61. Griffin IJ, Cooke RJ (2012) Development of whole body adiposity in preterm infants. Early Hum Dev 88(Suppl 1):S19-S24

62. Euser AM, Finken MJ, Keijzer-Veen MG, Hille ET, Wit JM, Dekker FW (2005) Associations between prenatal and infancy weight gain and BMI, fat mass, and fat distribution in young adulthood: a prospective cohort study in males and females born very preterm. Am J Clin Nutr 81:480-487

63. Radmacher PG, Adamkin DH (2017) Fortification of human milk for preterm infants. Semin Fetal Neonatal Med 22:30-35

64. Brown JV, Embleton ND, Harding JE, McGuire W (2016) Multinutrient fortification of human milk for preterm infants. Cochrane Database Syst Rev:CD000343

65. O'Connor DL, Unger S (2013) Post-discharge nutrition of the breastfed preterm infant. Semin Fetal Neonatal Med 18:124-128

66. Morley R, Lucas A (2000) Randomized diet in the neonatal period and growth performance until 7.5-8 y of age in preterm children. Am J Clin Nutr 71:822-828

67. Huang P, Zhou J, Yin Y, Jing W, Luo B, Wang J (2016) Effects of breast-feeding compared with formula-feeding on preterm infant body composition: a systematic review and meta-analysis. $\mathrm{Br} \mathrm{J}$ Nutr 116:132-141

68. Amissah EA, Brown J, Harding JE (2020) Protein supplementation of human milk for promoting growth in preterm infants. Cochrane Database Syst Rev 9:Cd000433

69. O'Connor DL, Khan S, Weishuhn K, Vaughan J, Jefferies A, Campbell DM, Asztalos E, Feldman M, Rovet J, Westall C,
Whyte H, Postdischarge Feeding Study G (2008) Growth and nutrient intakes of human milk-fed preterm infants provided with extra energy and nutrients after hospital discharge. Pediatrics 121: 766-776

70. Aimone A, Rovet J, Ward W, Jefferies A, Campbell DM, Asztalos E, Feldman M, Vaughan J, Westall C, Whyte H, O'Connor DL, Post-Discharge Feeding Study G (2009) Growth and body composition of human milk-fed premature infants provided with extra energy and nutrients early after hospital discharge: 1 -year followup. J Pediatr Gastroenterol Nutr 49:456-466

71. Dogra S, Thakur A, Garg P, Kler N (2017) Effect of differential enteral protein on growth and neurodevelopment in infants $<1500$ g: a randomized controlled trial. J Pediatr Gastroenterol Nutr 64: e126-e132

72. Miller J, Makrides M, Gibson RA, McPhee AJ, Stanford TE, Morris S, Ryan P, Collins CT (2012) Effect of increasing protein content of human milk fortifier on growth in preterm infants born at $<31$ wk gestation: a randomized controlled trial. Am J Clin Nutr 95: 648-655

73. Amissah EA, Brown J, Harding JE (2020) Fat supplementation of human milk for promoting growth in preterm infants. Cochrane Database Syst Rev 8:Cd000341

74. Amissah EA, Brown J, Harding JE (2020) Carbohydrate supplementation of human milk to promote growth in preterm infants. Cochrane Database Syst Rev 9:Cd000280

75. Horta BL, Loret de Mola C, Victora CG (2015) Long-term consequences of breastfeeding on cholesterol, obesity, systolic blood pressure and type 2 diabetes: a systematic review and meta-analysis. Acta Paediatr 104:30-37

76. Belfort M, Cherkerzian S, Bell K, Soldateli B, Cordova Ramos E, Palmer C, Steele T, Pepin H, Ellard D, Drouin K, Inder T (2020) Macronutrient intake from human milk, infant growth, and body composition at term equivalent age: a longitudinal study of hospitalized very preterm infants. Nutrients 12

77. Walsh V, Brown JVE, Askie LM, Embleton ND, McGuire W (2019) Nutrient-enriched formula versus standard formula for preterm infants. Cochrane Database Syst Rev 7:CD004204

78. Miller J, Tonkin E, Damarell RA, McPhee AJ, Suganuma M, Suganuma H, Middleton PF, Makrides M, Collins CT (2018) A systematic review and meta-analysis of human milk feeding and morbidity in very low birth weight infants. Nutrients 10

79. Hay WW Jr, Brown LD, Denne SC (2014) Energy requirements, protein-energy metabolism and balance, and carbohydrates in preterm infants. World Rev Nutr Diet 110:64-81

80. Young L, Embleton ND, McGuire W (2016) Nutrient-enriched formula versus standard formula for preterm infants following hospital discharge. Cochrane Database Syst Rev 12:CD004696

81. Amesz EM, Schaafsma A, Cranendonk A, Lafeber HN (2010) Optimal growth and lower fat mass in preterm infants fed a protein-enriched postdischarge formula. J Pediatr Gastroenterol Nutr 50:200-207

82. Roggero P, Gianni ML, Amato O, Liotto N, Morlacchi L, Orsi A, Piemontese P, Taroni F, Morniroli D, Bracco B, Mosca F (2012) Growth and fat-free mass gain in preterm infants after discharge: a randomized controlled trial. Pediatrics 130:e1215-e1221

83. Cooke RJ, McCormick K, Griffin IJ, Embleton N, Faulkner K, Wells JC, Rawlings DC (1999) Feeding preterm infants after hospital discharge: effect of diet on body composition. Pediatr Res 46: 461-464

84. Cooke RJ, Griffin IJ, McCormick K (2010) Adiposity is not altered in preterm infants fed with a nutrient-enriched formula after hospital discharge. Pediatr Res 67:660-664

85. Lapillonne A, Salle BL, Glorieux FH, Claris O (2004) Bone mineralization and growth are enhanced in preterm infants fed an isocaloric, nutrient-enriched preterm formula through term. Am J Clin Nutr 80:1595-1603 
86. Picaud JC, Decullier E, Plan O, Pidoux O, Bin-Dorel S, van Egroo LD, Chapuis F, Claris O (2008) Growth and bone mineralization in preterm infants fed preterm formula or standard term formula after discharge. J Pediatr 153:616-621 621 e611-612

87. Embleton ND, Cooke RJ (2005) Protein requirements in preterm infants: effect of different levels of protein intake on growth and body composition. Pediatr Res 58:855-860

88. De Curtis M, Pieltain C, Rigo J (2002) Body composition in preterm infants fed standard term or enriched formula after hospital discharge. Eur J Nutr 41:177-182

89. Gianni ML, Roggero P, Orsi A, Piemontese P, Garbarino F, Bracco B, Garavaglia E, Agosti M, Mosca F (2014) Body composition changes in the first 6 months of life according to method of feeding. J Hum Lact 30:148-155

90. Koo WW, Hockman EM (2006) Posthospital discharge feeding for preterm infants: effects of standard compared with enriched milk formula on growth, bone mass, and body composition. Am J Clin Nutr 84:1357-1364

91. Ruys CA, van de Lagemaat M, Finken MJ, Lafeber HN (2017) Follow-up of a randomized trial on postdischarge nutrition in preterm-born children at age $8 \mathrm{y}$. Am J Clin Nutr 106:549-558

92. Ruys CA, Broring T, van Schie PEM, van de Lagemaat M, Rotteveel J, Finken MJJ, Oostrom KJ, Lafeber HN (2019) Neurodevelopment of children born very preterm and/or with a very low birth weight: 8-Year follow-up of a nutritional RCT. Clinical Nutrition ESPEN 30:190-198

93. Cooke RJ, Embleton ND, Griffin IJ, Wells JC, McCormick KP (2001) Feeding preterm infants after hospital discharge: growth and development at 18 months of age. Pediatr Res 49:719-722
94. Michaelsen KF, Greer FR (2014) Protein needs early in life and long-term health. Am J Clin Nutr 99:718S-722S

95. Villar J, Giuliani F, Bhutta ZA, Bertino E, Ohuma EO, Ismail LC, Barros FC, Altman DG, Victora C, Noble JA, Gravett MG, Purwar M, Pang R, Lambert A, Papageorghiou AT, Ochieng R, Jaffer YA, Kennedy SH, International F, Newborn Growth Consortium for the C (2015) Postnatal growth standards for preterm infants: the Preterm Postnatal Follow-up Study of the INTERGROWTH21(st) Project. Lancet Glob Health 3:e681-e691

96. Villar J, Giuliani F, Barros F, Roggero P, Coronado Zarco IA, Rego MAS, Ochieng R, Gianni ML, Rao S, Lambert A, Ryumina I, Britto C, Chawla D, Cheikh Ismail L, Ali SR, Hirst J, Teji JS, Abawi K, Asibey J, Agyeman-Duah J, McCormick K, Bertino E, Papageorghiou AT, Figueras-Aloy J, Bhutta Z, Kennedy S (2018) Monitoring the postnatal growth of preterm infants: a paradigm change. Pediatrics 141:e20172467

97. Hansen-Pupp I, Lofqvist C, Polberger S, Niklasson A, Fellman V, Hellstrom A, Ley D (2011) Influence of insulin-like growth factor I and nutrition during phases of postnatal growth in very preterm infants. Pediatr Res 69:448-453

98. Gidrewicz DA, Fenton TR (2014) A systematic review and metaanalysis of the nutrient content of preterm and term breast milk. BMC Pediatr 14:216

99. Boyce C, Watson M, Lazidis G, Reeve S, Dods K, Simmer K, McLeod G (2016) Preterm human milk composition: a systematic literature review. Br J Nutr 116:1033-1045

Publisher's note Springer Nature remains neutral with regard to jurisdictional claims in published maps and institutional affiliations. 